\title{
Effects of Citrus limon Extract on Oxidative Stress-Induced Nitric Oxide Generation and Bovine Teeth Bleaching
}

\author{
Soon-Jeong Jeong ${ }^{\dagger}$ \\ Department of Dental Hygiene \& Institute of Basic Science for Well-Aging, Youngsan University, Yangsan \\ 50510, Korea
}

\begin{abstract}
Background: We aimed to investigate the effect of Citrous limon extract (CLE) on oxidative stress-induced cytotoxicity and nitric oxide (NO) generation and the tooth bleaching effect of CLE as a substitute for hydrogen peroxide $\left(\mathrm{H}_{2} \mathrm{O}_{2}\right)$ and determine the feasibility and application of CLE as a safe and effective natural tooth bleaching agent.

Methods: The protective effect of $\mathrm{CLE}$ on $\mathrm{H}_{2} \mathrm{O}_{2}$-induced cytotoxicity in Raw264. 7 macrophages was investigated by the MTT assay. The inhibitory effect of CLE on the generation of $\mathrm{H}_{2} \mathrm{O}_{2}$-induced $\mathrm{NO}$ was confirmed by the $\mathrm{NO}$ assay, and the changes in inducible nitric oxide synthase (iNOS) protein expression were confirmed by western blotting. Stained bovine teeth were treated with/without $15 \%$ and/or $35 \% \mathrm{CLE}$ and $\mathrm{H}_{2} \mathrm{O}_{2}, 15 \%$ sodium bicarbonate $\left(\mathrm{NaHCO}_{3}\right)$ for 3 hours, and were irradiated with/without bleaching light (BL) for 15 minutes. The color change of the treated bovine tooth surface was measured using a colorimeter. Results: The viability of Raw264.7 cells treated with each concentration of CLE and $500 \mu \mathrm{M} \mathrm{H} \mathrm{H}_{2} \mathrm{O}_{2}$ significantly increased as CLE increased, and NO generation and iNOS protein expression were significantly reduced in cells treated with $300 \mu \mathrm{g} \mathrm{CLE}+/ 500 \mu \mathrm{M}$ $\mathrm{H}_{2} \mathrm{O}_{2}+$ and $300 \mu \mathrm{g} \mathrm{CLE}+/ 500 \mu \mathrm{M} \mathrm{H}_{2} \mathrm{O}_{2}+/ 150 \mu \mathrm{g} \mathrm{NaHCO}{ }_{3}+$. The bleaching effect of $35 \% \mathrm{CLE}+$ was higher than that of $15 \% \mathrm{CLE}+$ and $15 \% \mathrm{NaHCO}_{3}+$, and the effect was similar to that of $15 \% \mathrm{H}_{2} \mathrm{O}_{2}+$. The $35 \% \mathrm{CLE}+/ 15 \% \mathrm{NaHCO}_{3}+$ showed the greatest bleaching effect and was higher than that of the groups irradiated with the $\mathrm{BL}$. The greatest bleaching effect was observed with $35 \% \mathrm{CLE}+/ 15 \%$ $\mathrm{NaHCO}_{3}+$, followed by $35 \% \mathrm{H}_{2} \mathrm{O}_{2}+/ \mathrm{BL}+$.

Conclusion: CLE inhibited oxidative stress-induced cytotoxicity and NO generation in Raw264.7 cells and, could replace $\mathrm{H}_{2} \mathrm{O}_{2}$, which causes side effects and risks in teeth breaching treatment. It showed greatest teeth bleaching effect when combined with $\mathrm{NaHCO}_{3}$. CLE is an effective and safe natural tooth bleaching substitute.
\end{abstract}

Key Words: Citrus limon, Hydrogen peroxide, Nitric oxide, Oxidative stress, Tooth bleaching

\section{Introduction}

With an increasing interest in beauty treatments, concurrent with economic growth, patients visiting dental clinics have increased chances of receiving not only simple treatment for dental caries and periodontal diseases, but also tooth bleaching treatment for esthetic improvement ${ }^{1,2)}$. Tooth discoloration is caused by intrinsic and extrinsic factors. Intrinsic factors are associated with a pathology of the pulp, drugs, such as tetracycline and fluoride, certain systemic diseases, and tooth dysplasia, while extrinsic factors are associated with externally colored substances, such as cigarettes, coffee, and wine ${ }^{3)}$. As a treatment for discoloration of teeth, tooth bleaching is mainly used to preserve the tooth body and improve the tone of the teeth ${ }^{3)}$. There are two types of tooth bleaching: in-office bleaching using 30 to $35 \%$ high concentration hydrogen peroxide $\left(\mathrm{H}_{2} \mathrm{O}_{2}\right)$, performed at dental clinics, and home bleaching using a low concentration of 10 to $15 \% \mathrm{H}_{2} \mathrm{O}_{2}{ }^{4-6)}$. In-office bleaching involves the application of a bleaching agent for a short period of time by a dentist in a dental clinic, and the dentist applies a bleaching agent 
to teeth after protecting the soft tissue of the patient and induces additional activity with heat or light ${ }^{7}$. In office tooth bleaching involves a strong light capable of inducing photolysis of $\mathrm{H}_{2} \mathrm{O}_{2}$ with high-frequency and special wavelengths of less than $248 \mathrm{~nm}$ and heat, which activates thermocatalysis increasing the breakdown of $\mathrm{H}_{2} \mathrm{O}_{2}$ to hydroxyl radicals ${ }^{8,9)}$. Home bleaching involves the application of a low-concentration bleaching agent to the teeth at home under the guidance of a dentist and has the advantages of convenience and low cost ${ }^{10)} \cdot \mathrm{H}_{2} \mathrm{O}_{2}$ and carbamide peroxide are mainly used as tooth bleaching agents ${ }^{11)}$. $\quad \mathrm{H}_{2} \mathrm{O}_{2}$ is a strong oxidizing agent that decomposes water and unstable free radicals ${ }^{12)}$. Free radicals react with the staining material to exert tooth bleaching effects ${ }^{7,13)}$. However, $\mathrm{H}_{2} \mathrm{O}_{2}$ changes the enamel surface to become rough and porous ${ }^{14,15)}$ and induces side effects such as dentin hypersensitivity, swollen gingiva, inflammation, and bleeding ${ }^{16,17)}$. Therefore, it is necessary to develop a safe tooth bleaching agent to replace $\mathrm{H}_{2} \mathrm{O}_{2}$.

Recently, there has been increasing interest in revealing the functionality of natural products with fewer side effects and safety, and the use of natural products for the prevention and treatment of various diseases ${ }^{18)}$. Citrus limon extract (CLE) is a citrus fruit that is consumed worldwide and contains various phenolic compounds and flavonoids ${ }^{19)}$. More than $90 \%$ of the ingredients are bioflavonoids, including hesperidin (vitamin P), neohesperidin, naringin, and the structure of more than 60 of its ingredients has been revealed ${ }^{20)}$. These ingredients not only have various physiological activities, including antioxidant activity, hyperlipidemia suppression, tooth caries prevention effect, antibacterial effect, blood pressure strengthening effect, and anti-ulcer effect ${ }^{21,22)}$ but are also known for their potential use in tooth bleaching ${ }^{23)}$. However, studies on the effects of tooth bleaching and application methods are still insufficient. The purpose of this study was to therefore investigate the effect of CLE on oxidative stress-induced cytotoxicity and nitric oxide (NO) generation and the tooth bleaching effect of CLE as a substitute for $\mathrm{H}_{2} \mathrm{O}_{2}$ which causes side effects, and to determine the possibility and application of CLE as a safe and effective natural tooth bleaching agent.

\section{Materials and Methods}

\section{Cell culture}

Raw264.7 macrophages (Korean Cell Line Bank, Seoul, Korea) were cultured in Dulbecco's modified Eagle's medium containing $10 \%$ fetal bovine serum and $1 \%$ antibiotic-antimycotic solution (all from WelGENE Inc., Daegu, Korea) in a $5 \% \mathrm{CO}_{2}$ incubator at $37^{\circ} \mathrm{C}$.

\section{Preparation of Citrus limon extract and bleaching agents}

Freeze-dried CLE (Sanmaeul Co., Ltd., Changnyeong, Korea) was dissolved in D.W. at an appropriate concentration and filtered through a filter paper (Whatman Inc., Maidstone, UK) and syringe filter (Minisart ${ }^{R}$; Sartorius, Göttingen, Germany), before use. Fifteen \% sodium bicarbonate $\left(\mathrm{NaHCO}_{3}\right.$, Arm \& Hammer Baking soda; Yuhan Corp., Seoul, Korea) and $15 \% \mathrm{H}_{2} \mathrm{O}_{2}$ (Sigma-Aldrich Co., St. Louis, MO, USA) were used as positive controls for the comparison of the bleaching effect. The bovine teeth were treated with CLE and the bleaching agents for 3 hours, and the bleaching light (BL) (Light Radiator; KMG, Busan, Korea) was applied twice for 15 minutes.

\section{Assessment of cell viability}

The effect of CLE on cytotoxicity was assessed using the methylthiazolydiphenyl-tetrazolium bromide (MTT) assay. Raw264.7 macrophages were seeded on 96 well plates $\left(1 \times 10^{3}\right.$ cells/well $)$ and treated with various concentrations of CLE for 1 hour before treatment with $500 \mu \mathrm{M} \mathrm{H} \mathrm{O}_{2}$ for 24 hours. MTT (Sigma-Aldrich Co.) was added to the prepared cells and incubated in the dark for 3 hours. After removal of the MTT solution, the cells were treated with $200 \mu \mathrm{L}$ of $5 \%$ dimethylsulfoxide (Sigma-Aldrich Co.). Viable cells were assayed at $540 \mathrm{~nm}$ using an enzyme-linked immunosorbent assay (ELISA) microplate reader (Molecular Devices, Sunnyvale, CA, USA).

\section{Nitic oxide assay}

Raw264.7 macrophages were treated with $300 \mu \mathrm{g}$ CLE and/or $150 \mu \mathrm{g} \mathrm{NaHCO}_{3}$ (ThermoFisher Scientific Inc., Waltham, MS, USA) for 1 hour before treatment with 500 
$\mu \mathrm{M} \mathrm{H}_{2} \mathrm{O}_{2}$ for 24 hours. Supernatants from the prepared cells were treated with Griess reagent (Sigma-Aldrich Chemical Co.) for 10 minutes at room temperature. NO concentrations were measured at $540 \mathrm{~nm}$ using the ELISA reader.

\section{Protein isolation and western blot analysis}

Total protein was isolated and quantified according to a previously described method ${ }^{18)}$ For the western blot analysis, the prepared total protein was electrophoresed on $10 \%$ sodium dodecyl sulfate polyacrylamide gels and transferred onto polyvinylidene difluoride membranes (Schleicher \& Schuell, Keene, NH, USA). The membranes were probed with 1:1,000 anti-mouse inducible nitric oxide synthase (iNOS, BD Bioscience, San Jose, CA, USA) and 1:1,000 anti-mouse actin (Santa Cruz Biotechnology Inc., Santa Cruz, CA, USA) primary antibodies. After washing, the membranes were blotted with horseradish peroxide-conjugated secondary antibodies (dilution, 1:500; goat anti-rabbit IgG-HRP; Santa Cruz Biotechnology Inc.). The protein bands were detected with ECL solution (Merck Millipore) and measured using a Science Lab Image Guage (FUJI FILM, Tokyo, Japan).

\section{Preparation of the bovine teeth and measurement of the color of the bovine teeth surface}

Bovine teeth without caries, fracture and cracks were selected and manufactured in $4 \times 4 \mathrm{~mm}$ using a diamond bur and high-speed handpiece, and stained with coffee for 24 hours. Before and after treatment with CLE and bleaching agents, the bovine teeth were washed twice with DW, and after removing excess moisture, changes in the color of the bovine teeth were measured using a colorimeter (Konica minolta, Tokyo, Japan) 3 times in the same environment and conditions. Color values were determined using the previously reported CIE $\mathrm{L} * \mathrm{~A}^{*} \mathrm{~B} *$ colorimetric method $^{24)}$. In the CIE $L^{*} A^{*} B^{*}$ value, $L^{*}$ is the contrast, $a^{*}$ is the red-green color, and $\mathrm{b}^{*}$ is the yellow-blue color, and the following equation was used to measure the amount of color change:

$$
\Delta E=\sqrt{\left(L^{*}\right)^{2}+\left(a^{*}\right)^{2}+\left(b^{*}\right)^{2}}
$$

\section{Statistical analysis}

All experiments were performed at least in triplicate. Data are reported as means \pm standard deviation, calculated using SPSS (version 12.0; SPSS Inc., Chicago, IL, USA). Significant differences $\left({ }^{*} \mathrm{p}<0.05,{ }^{* *} \mathrm{p}<0.01,{ }^{* * *} \mathrm{p}<\right.$ 0.001 ) were determined by independent samples t-test.

\section{Results}

\section{Protective effect of Citrus limon extract against $\mathrm{H}_{2} \mathrm{O}_{2}$-induced cytotoxicity in \\ Raw264. 7 macrophage}

The protective effect of CLE on the oxidative stress-induced cytotoxicity of $500 \mu \mathrm{M} \mathrm{H}_{2} \mathrm{O}_{2}$ in Raw264.7 macrophages was investigated by the MTT assay. CLE treatment with each concentration did not show cytotoxicity in Raw264.7 cells, but $500 \mu \mathrm{M} \mathrm{H}_{2} \mathrm{O}_{2}$ was cytotoxic and the cell viability was significantly reduced

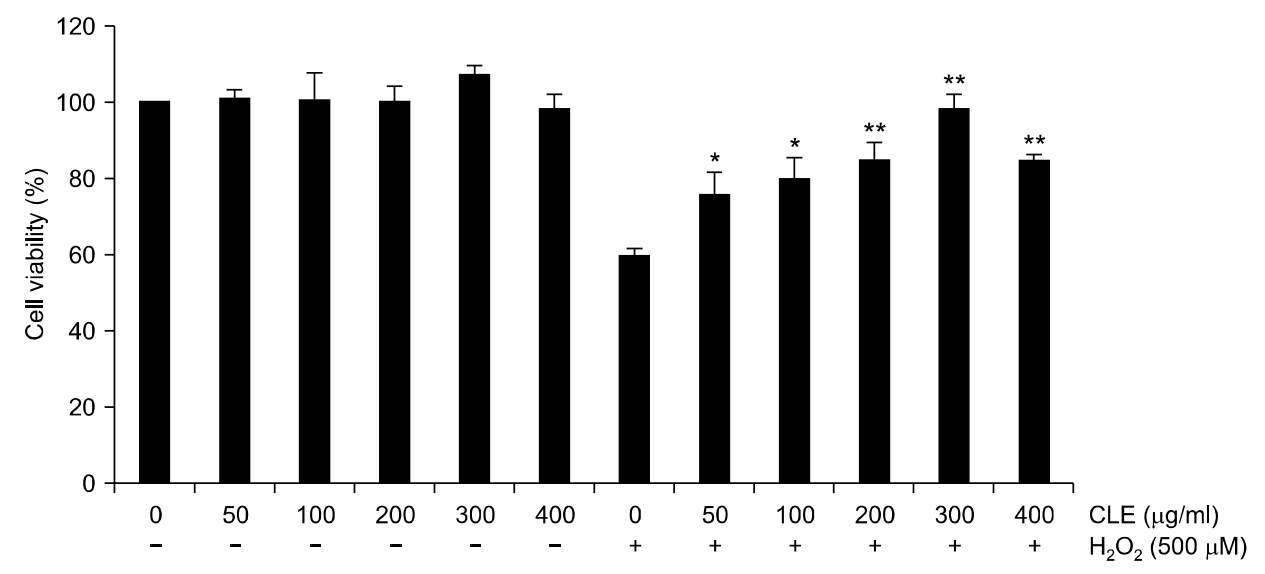

Fig. 1. Protective effect of Citrus limon extract (CLE) against $\mathrm{H}_{2} \mathrm{O}_{2}$-induced cytotoxicity in RAW264.7 macrophage. Raw264.7 cells were treated with various concentration of CLE and 500 $\mu \mathrm{M} \mathrm{H}_{2} \mathrm{O}_{2}$ for 24 hours, and cell viability was measured by MTT assay. The results are represented the mean \pm standard deviation of independent three times experiments. ${ }^{*} \mathrm{p}<0.05,{ }^{* *} \mathrm{p}<0.01$ compared with the $\mathrm{H}_{2} \mathrm{O}_{2}+$ group. 
A

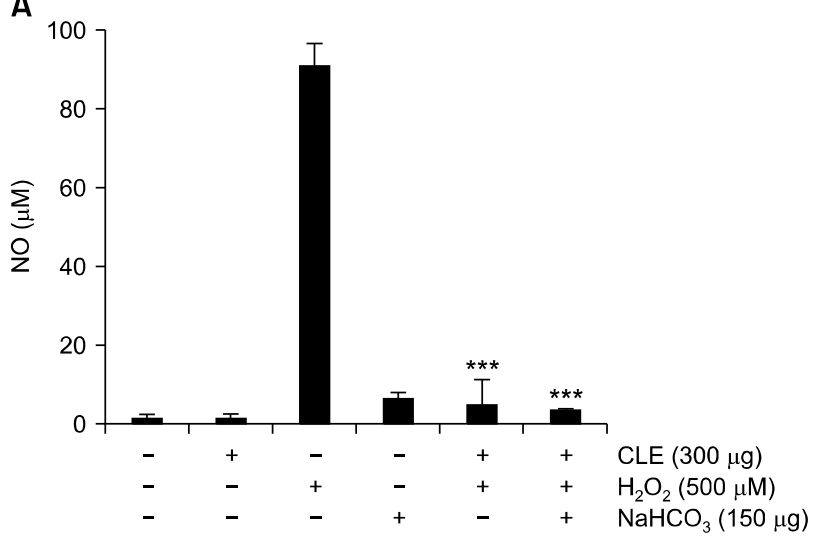

B

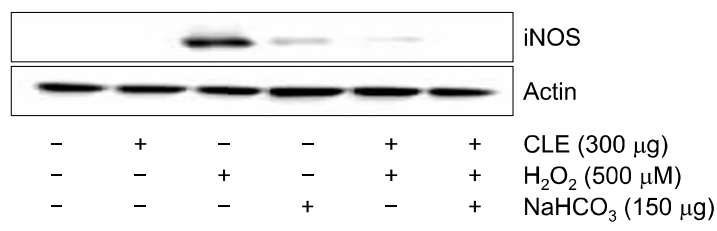

Fig. 2. Inhibitory effect of Citrus limon extract (CLE) on $\mathrm{H}_{2} \mathrm{O}_{2}-$ induced nitric oxide (NO) generation in RAW264.7 macrophage. (A) Raw264. 7 cells were treated with/without $300 \mu \mathrm{g} \mathrm{CLE}, 500 \mu \mathrm{M}$ $\mathrm{H}_{2} \mathrm{O}_{2}$ and/or $75 \mu \mathrm{g} \mathrm{NaHCO}$ for 24 hours, and the levels of NO were measured by nitric oxide assay. The results are represented the mean \pm standard deviation of independent three times experiments. (B) The cellular proteins were prepared, and inducible nitric oxide synthase (iNOS) and actin protein levels were measured by Western blot analysis. Actin was used as internal control for the Western blot analysis. The results are represented the mean \pm standard deviation of independent three times experiments. ${ }_{* * *} \mathrm{p}<0.001$ compared with the $\mathrm{H}_{2} \mathrm{O}_{2}+$ group.
(Fig. 1). The cell viability of $\mathrm{CLE}+/ 500 \mu \mathrm{M} \mathrm{H}_{2} \mathrm{O}_{2}+$ significantly increased with the concentration of CLE.

\section{Inhibitory effect of Citrus limon extract on $\mathrm{H} 2 \mathrm{O} 2$-induced nitric oxide generation in Ras264. 7 macrophage}

$\mathrm{NO}$ is a representative pro-inflammatory mediator induced by lipopolysaccharide, $\mathrm{H}_{2} \mathrm{O}_{2}$, and ultraviolet irradiation, and its production is regulated by the synthesizing enzyme, $\mathrm{iNOS}^{18)}$. The effects of CLE and $\mathrm{NaHCO}_{3}$ on $\mathrm{NO}$ generation and iNOS protein expression were confirmed in Raw264.7 cells (Fig. 2). Treatment with $300 \mu \mathrm{g}$ CLE and $150 \mu \mathrm{g} \mathrm{NaHCO}_{3}$ did not affect NO generation or iNOS protein expression in Raw264.7 cells but $500 \mu \mathrm{M} \mathrm{H}_{2} \mathrm{O}_{2}$ significantly increased NO generation and iNOS protein expression. NO generation and iNOS protein expression in Raw264.7 cells treated with $300 \mu \mathrm{g}$ $\mathrm{CLE}+/ 500 \mu \mathrm{M} \mathrm{H}_{2} \mathrm{O}_{2}+$ were significantly reduced, indicating that CLE has an inhibitory effect on oxidative stress induced by $\mathrm{H}_{2} \mathrm{O}_{2}$.

A
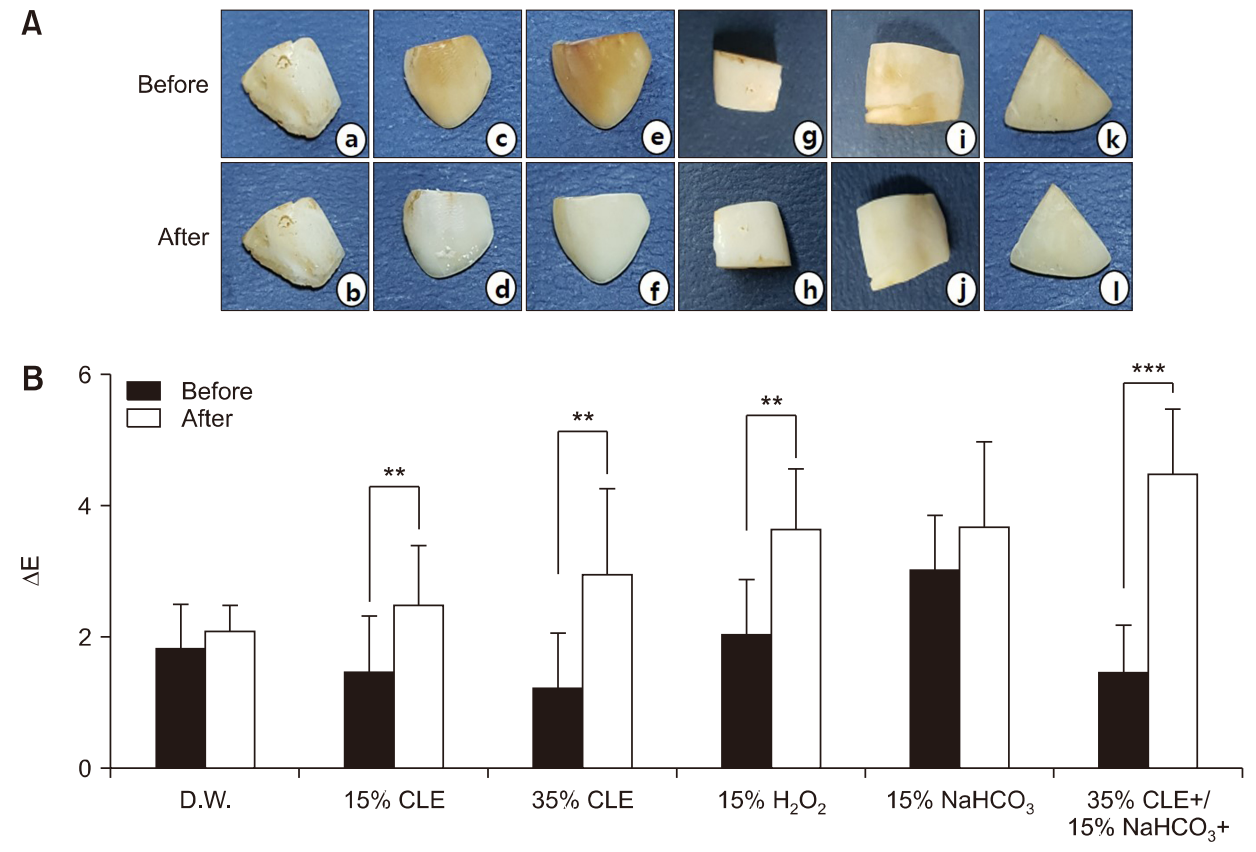

Fig. 3. Whitening effect of Citrus limon extract (CLE) and bleaching agents on bovine teeth. (A) Bovine teeth treated with CLE and bleaching agents. Before treated with (a) D.W., (c) $15 \% \mathrm{CLE}$, (e) $35 \% \mathrm{CLE}$, (g) $15 \%$ $\mathrm{H}_{2} \mathrm{O}_{2}$, (i) $15 \% \mathrm{NaHCO}_{3}$, (k) $35 \% \mathrm{CLE}+$ $15 \% \mathrm{NaHCO}_{3}$. After treated with (b) $\mathrm{DW}$, (d) $15 \% \mathrm{CLE}$, (f) $35 \% \mathrm{CLE}$, (h) $15 \% \mathrm{H}_{2} \mathrm{O}_{2}$, (j) $15 \% \mathrm{NaHCO}_{3}$, (I) $35 \%$ $\mathrm{CLE}+15 \% \mathrm{NaHCO}_{3}$. (B) Results of quantitative analysis of whitening effect of CLE and bleaching agents. The results are represented the mean \pm standard deviation of independent three times experiments. ${ }^{* *} p<0.01,{ }^{* * *} p<0.001$. 
Table 1. Effect of CLE and Bleaching Agents on Bovine Teeth according to the Application of BL

\begin{tabular}{lcccr}
\multicolumn{1}{c}{ Group } & Number of patients & Before & After & $\begin{array}{r}\text { Bleaching rate } \\
\left(\% \text { of } 15 \% \mathrm{H}_{2} \mathrm{O}_{2}\right)\end{array}$ \\
\hline $\mathrm{D} . \mathrm{W}$. & 5 & $1.85 \pm 0.65$ & $2.08 \pm 0.40$ & 14.50 \\
$15 \% \mathrm{CLE}$ & 9 & $1.48 \pm 0.84$ & $2.48 \pm 0.90$ & 62.89 \\
$35 \% \mathrm{CLE}$ & 9 & $1.25 \pm 0.82$ & $2.95 \pm 1.30$ & 106.92 \\
$15 \% \mathrm{H}_{2} \mathrm{O}_{2}($ Hydrogen peroxide) & 9 & $2.04 \pm 0284$ & $3.63 \pm 0.9$ & 100.00 \\
$15 \% \mathrm{NaHCO}_{3}$ (Sodium bicarbonate) & 9 & $3.02 \pm 0.82$ & $3.66 \pm 1.30$ & 40.25 \\
$35 \% \mathrm{CLE}^{\prime} / 15 \% \mathrm{NaHCO}_{3}+$ & 5 & $1.48 \pm 0.71$ & $4.45 \pm 1.00$ & 186.79 \\
\hline $35 \% \mathrm{H}_{2} \mathrm{O}_{2}+\mathrm{BL}+$ & 9 & $2.07 \pm 0.98$ & $4.07 \pm 1.24$ & 126.00 \\
$35 \% \mathrm{CLE}+/ \mathrm{BL}+$ & 9 & $2.83 \pm 1.06$ & $3.66 \pm 1.03$ & 52.00 \\
$35 \% \mathrm{CLE}+/ 15 \% \mathrm{NaHCO}_{3}+/ \mathrm{BL}+$ & 9 & $2.15 \pm 0.99$ & $3.57 \pm 1.03$ & 89.00 \\
\hline
\end{tabular}

Values are presented as mean \pm standard deviation.

CLE: Citrus limon extract, BL: bleaching light.

A
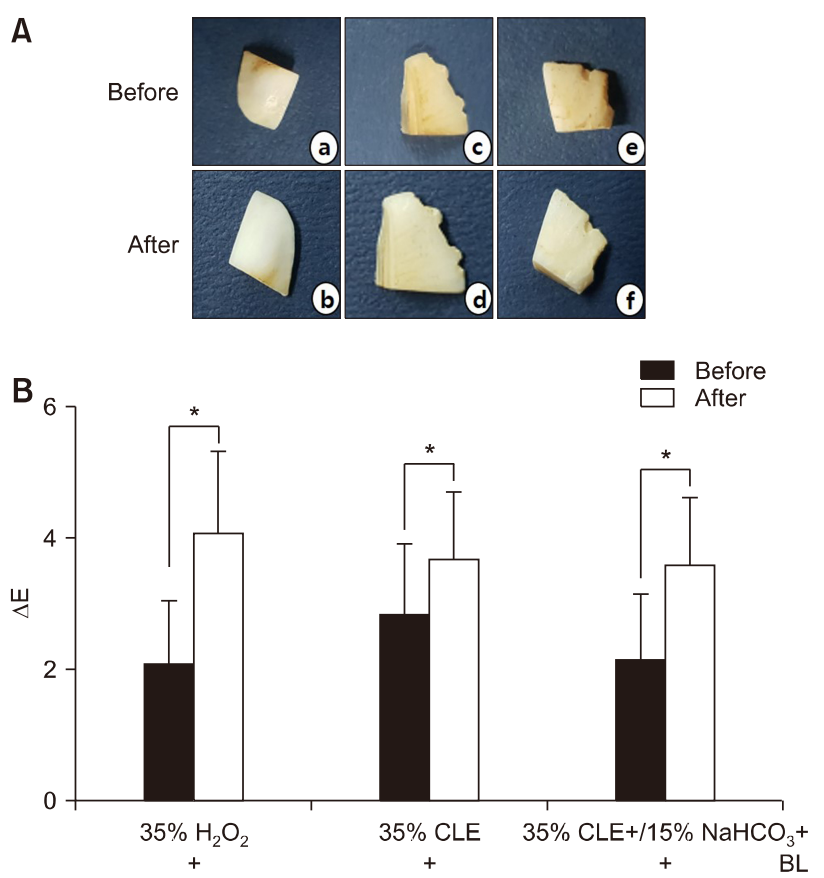

Fig. 4. Bleaching effect of Citrus limon extract (CLE) and bleaching agents on bovine teeth according to the application of bleaching light. (A) Bleaching light (BL)-applied bovine teeth after CLE and bleaching agents treatment. Before treated with (a) $35 \%$ $\mathrm{H}_{2} \mathrm{O}_{2}+\mathrm{BL}$, (c) $35 \% \mathrm{CLE}+\mathrm{BL}$, (e) $35 \% \mathrm{CLE}+15 \% \mathrm{NaHCO}_{3}+\mathrm{BL}$. After treated with (b) $35 \% \mathrm{H}_{2} \mathrm{O}_{2}+\mathrm{BL}$, (d) $35 \% \mathrm{CLE}+\mathrm{BL}$, (f) $35 \% \mathrm{CLE}+15 \%$ $\mathrm{NaHCO}_{3}+\mathrm{BL}$. (B) Results of quantitative analysis of bleaching effect of BL-applied bovine teeth after CLE and bleaching agents treatment. The results are represented the mean \pm standard deviation of independent three times experiments. ${ }^{*} p<0.05$.

3. Bleaching effect of Citrus limon extract and the bleaching agents on the bovine teeth according to the irradiation with bleaching light

The bleaching effect after treatment with CLE and the bleaching agents for 3 hours on stained bovine teeth was investigated (Fig. 3, Table 1). The effect of 35\% CLE+ was higher than that of $15 \% \mathrm{CLE}+$ and $15 \% \mathrm{NaHCO}_{3}+$, and the effect was similar to that of $15 \% \mathrm{H}_{2} \mathrm{O}_{2}+$. The $35 \%$ $\mathrm{CLE}+15 \% \mathrm{NaHCO}_{3}+$ showed the greatest bleaching effect, and the result was higher than that of the groups with $\mathrm{BL}$ irradiation. $35 \% \mathrm{H}_{2} \mathrm{O}_{2}+/ \mathrm{BL}+$ showed a high bleaching effect compared to groups with $\mathrm{BL}$ irradiation, and $35 \% \mathrm{CLE}+/ \mathrm{BL}+$ and $35 \% \mathrm{CLE}+/ 15 \% \mathrm{NaHCO}_{3}+/$ $\mathrm{WL}+$ significantly reduced the bleaching effect compared to groups without BL irradiation (Fig. 4, Table 1). The bleaching effect of CLE and bleaching agents according to BL irradiation is shown as a ratio of $15 \% \mathrm{H}_{2} \mathrm{O}_{2}+$ in Fig. 5 . $35 \% \mathrm{CLE}+15 \% \mathrm{NaHCO}_{3}+$ had the greatest effect, followed by $35 \% \mathrm{H}_{2} \mathrm{O}_{2}+/ \mathrm{BL}+$.

\section{Discussion}

Stimulation by excessive oxidative stress in macrophages, monocytes, hepatocytes, bone marrow cells, and smooth muscle cells induces inflammation and immune responses and increases iNOS expression ${ }^{18)}$. As a result, NO, an indicator of the inflammatory response, is produced ${ }^{25)}$. NO has various physiological activities such as the induction of vascular regulation, immune responses and signaling function but large amounts of NO cause inflammation, tissue damage, and genetic mutation ${ }^{26)}$. Therefore, there is increasing interest in substances with inhibitory activities against excessive oxidative stress and inflammatory mediators during bleaching treatment using $\mathrm{H}_{2} \mathrm{O}_{2}$. Citrus 


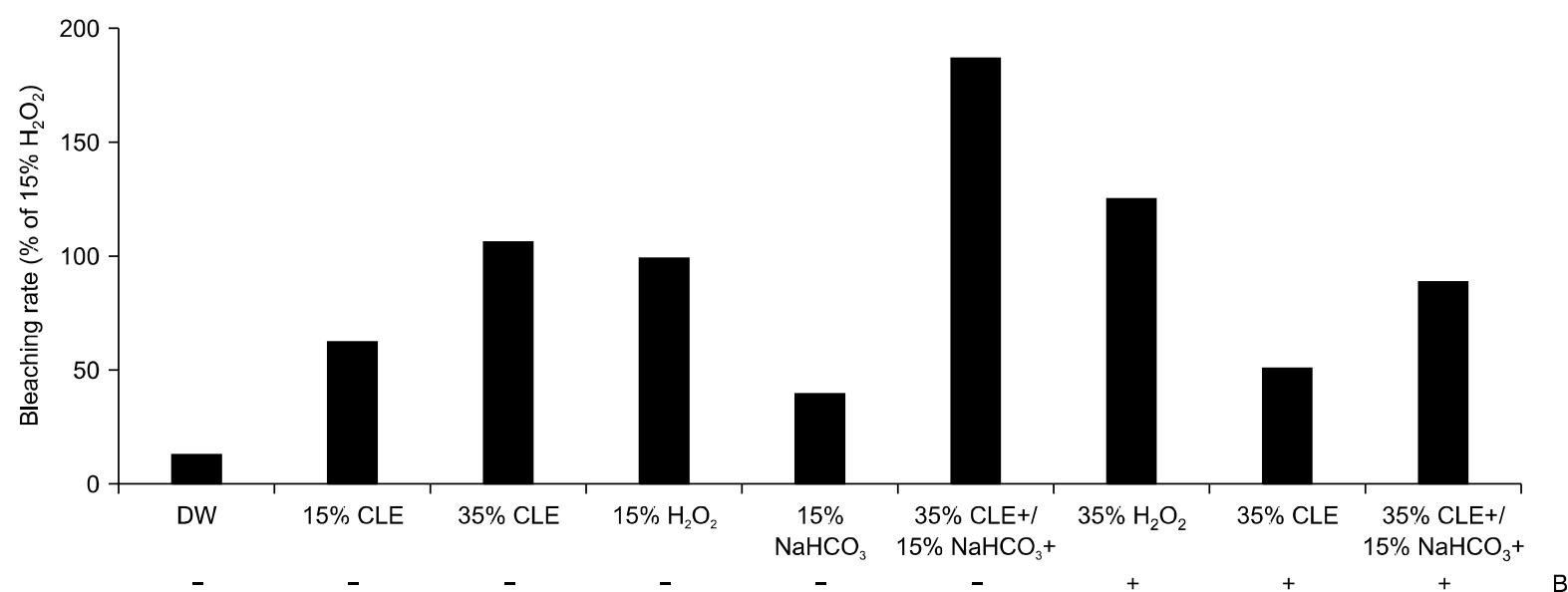

Fig. 5. Bleaching rate of Citrus limon extract (CLE) and bleaching agents on bovine teeth according to bleaching light (BL) irradiation. The results are represented the mean \pm stnadard deviation of independent three times experiments.

limon is consumed as a food in many countries worldwide and has numerous physiological activities ${ }^{21,22)}$. Among the components of CLE, citric acid has a fatigue recovery effect, ascorbic acid has a scurvy prevention effect, bioflavonoids have an antioxidant effect, and hesperidin has a blood vessel strengthening effect ${ }^{21,22)}$. In this study, the cell viability of Raw 264.7 cells treated with $500 \mu \mathrm{M}$ $\mathrm{H}_{2} \mathrm{O}_{2}$ was significantly increased as the concentration of CLE increased (Fig. 1), and NO generation and iNOS protein expression were significantly reduced with the use of $300 \mu \mathrm{g} \mathrm{CLE}+/ 500 \mu \mathrm{M} \mathrm{H} \mathrm{H}_{2}$ (Fig. 2). These results indicate that CLE is a safe, natural product with inhibitory effects on oxidative stress-induced cytotoxicity and NO generation. Previous studies have also reported that CLE has antioxidant and anti-inflammatory effects, which is consistent with our results ${ }^{27)}$.

$\mathrm{NaHCO}_{3}$, commonly known as baking soda or bicarbonate of soda, is a non-toxic chemical compound used as a fermenting agent for baking and cooking ${ }^{28)}$, for $\mathrm{pH}$ control $^{29)}$, and as a medicine for indigestion and heartburn ${ }^{30)}$. In particular, $\mathrm{NaHCO}_{3}$ has anti-caries properties and is used as an ingredient in mouthwash and toothpaste ${ }^{28)}$. Although excessive $\mathrm{NaHCO}_{3}$ treatment has been reported to increase the generation of $\mathrm{NO}$ and tumor necrosis factor $\alpha$ in macrophages ${ }^{29}$, $\mathrm{NaHCO}_{3}$ did not affect iNOS and NO generation, and $300 \mu \mathrm{g} \mathrm{CLE}+/ 500$ $\mu \mathrm{M} \mathrm{H}_{2} \mathrm{O}_{2}+/ 150 \mu \mathrm{g} \mathrm{NaHCO}_{3}+$ inhibited iNOS and NO production (Fig. 2). Therefore, $\mathrm{NaHCO}_{3}$ can be used together without affecting the activity of CLE. In this study, 35\% CLE+ showed a bleaching effect similar to that of $15 \% \mathrm{H}_{2} \mathrm{O}_{2}+$, used for home bleaching, and $35 \%$ $\mathrm{CLE}+15 \% \mathrm{NaHCO}_{3}+$ showed a greater bleaching effect than $35 \% \mathrm{H}_{2} \mathrm{O}_{2}+/ \mathrm{BL}+$ for in-office bleaching (Fig. $3 \sim 5$, Table 1). This indicates that CLE can be applied as a substitute for $\mathrm{H}_{2} \mathrm{O}_{2}$ and treatment of $35 \%$ CLE and $15 \%$ $\mathrm{NaHCO}_{3}+$ is an effective and safe application method that can replace conventional tooth bleaching treatment.

As per the above results, CLE inhibited oxidative stress-induced cytotoxicity and $\mathrm{NO}$ generation in Raw264.7 cells, replacing $\mathrm{H}_{2} \mathrm{O}_{2}$ in terms of side effects and risk of teeth bleaching treatment, and increased the teeth bleaching effect by treatment with $\mathrm{NaHCO}_{3}$. Therefore, CLE is an effective and safe natural tooth bleaching substitute.

\section{Notes}

\section{Conflict of interest}

No potential conflict of interest relevant to this article was reported.

\section{Ethical approval}

This article is not necessary for IRB screening.

\section{ORCID}

Soon-Jeong Jeong, https://orcid.org/0000-0002-8959-4663 


\section{Acknowledgements}

This work was supported by Youngsan University Research Fund of 2020.

\section{References}

1. Yoon HS, Kim HJ: A clinical experimental study on tooth whitening effectiveness in toothpaste of containing natural extracts. J Korean Soc Dent Hyg 18: 19-29, 2018. https://doi.org/10.13065/jksdh.2018.18.01.19

2. Shin BG, Yang SE: The evaluation of clinical efficacy and longevity of home bleaching without combined application of In-office bleaching. J Korean Acad Conserv Dent 35: 387-394, 2010. https://doi.org/10.5395/JKACD.2010.35.5.387

3. Hwang GW, Choi MS, Lim SA: Improvement of bleaching effect on the color of enamel surface with $\mathrm{TiO} 2$ catalysis convergence bleaching agent. J Korea Converg Soc 6: 165-171, 2015. https://doi.org/10.15207/JKCS.2015.6.5.165

4. Ghassemi A, Vorwerk L, Hooper W, Cirigliano A, DeSciscio P, Nathoo S: Extrinsic stain removal effectiveness of a new whitening dentifrice. J Clin Dent 26: 72-75, 2015.

5. Karadas M, Duymus ZY: In vitro evaluation of the efficacy of different over-the-counter products on tooth whitening. Braz Dent J 26: 373-377, 2015. https://doi.org/10.1590/0103-64402013x0111

6. Karadas M, Hatipoglu O: Efficacy of mouthwashes containing hydrogen peroxide on tooth whitening. Scientific WorldJournal 2015: 961403, 2015. https://doi.org/10.1155/2015/961403

7. Greenwall L: Bleaching techniques in restorative dentistry: an illustrated guide. Taylor \& Francis Group, London, pp.31-60, 2001.

8. Buchalla W, Attin T: External bleaching therapy with activation by heat, light or laser--a systematic review. Dent Mater 23: 586-596, 2007. https://doi.org/10.1016/j.dental.2006.03.018

9. Carey CM: Tooth whitening: what we now know. J Evid Based Dent Pract 14 Suppl: 70-76, 2014. https://doi.org/10.1016/j.jebdp.2014.02.006

10. Woo GJ, Kim EK, Jeong SH, et al.: Comparison of the whitening effect of toothpastes containing $0.25 \%$ hydroxyapatite and $0.75 \%$ hydrogen peroxide. J Korean Acad Oral Health 38: 3-9, 2014. https://doi.org/10.11149/jkaoh.2014.38.1.3

11. Chung SM, Nam SY, Kwak DJ: Effect of tooth bleaching agents on color of tooth depend on content of carbamide peroxide. J Korean Acad Dent Technol 23: 85-93, 2001.

12. Dahl JE, Pallesen U: Tooth bleaching--a critical review of the biological aspects. Crit Rev Oral Biol Med 14: 292-304, 2003. https://doi.org/10.1177/154411130301400406

13. Park ES, Seong SR, Hong ST, et al.: A clinical evaluation of a bleaching strip containing $2.9 \%$ hydrogen peroxide. J Korean Acad Conserv Dent 31: 269-281, 2006. https://doi.org/10.5395/JKACD.2006.31.4.269

14. Haywood VB, Heymann HO: Nightguard vital bleaching: how safe is it? Quintessence Int 22: 515-523, 1991.

15. Zantner C, Beheim-Schwarzbach N, Neumann K, Kielbassa AM: Surface microhardness of enamel after different home bleaching procedures. Dent Mater 23: 243-250, 2007. https://doi.org/10.1016/j.dental.2006.06.044

16. Attin T, Kielbassa AM, Schwanenberg M, Hellwig E: Effect of fluoride treatment on remineralization of bleached enamel. J Oral Rehabil 24: 282-286, 1997. https://doi.org/10.1111/j.1365-2842.1997.tb00327.x

17. Crim GA: Post-operative bleaching: effect on microleakage. Am J Dent 5: 109-112, 1992.

18. Jeong MJ, Lim DS, Lee MH, Heo K, Kim HH, Jeong SJ: Inhibitory Effects on oral microbial activity and production of lipopolysaccharides-induced pro-inflammatory mediators in Raw264.7 macrophages of ethanol extract of Perilla flutescens (L.) Britton. J Dent Hyg Sci 20: 213-220, 2020. https://doi.org/10.17135/jdhs.2020.20.4.213

19. Noh JE, Yoon SR, Lim AK, Kim HJ, Huh D, Kim DI: A study on the yield of functional components of citrus peel extracts using optimized hot water extraction and enzymatic hydrolysis. Korean J Food Cook Sci 28: 51-55, 2012. https://doi.org/10.9724/KFCS.2012.28.1.051

20. Cheigh CI, Jung WG, Chung EY, et al.: Comparison on the extraction efficiency and antioxidant activity of flavonoid from citrus peel by different extraction methods. Food Eng Prog 14: 166-172, 2010.

21. Keys A: Mediterranean diet and public health: personal reflections. Am J Clin Nutr 61(6 Suppl): 1321S-1323S, 1995. 
https://doi.org/10.1093/ajen/61.6.1321S

22. Kim YD, Ko WJ, Koh KS, Jeon YJ, Kim SH: Composition of flavonoids and antioxidative activity from juice of Jeju native citrus fruits during maturation. Korean J Nutr 42: 278-290, 2009.

https://doi.org/10.4163/kjn.2009.42.3.278

23. Savarkar S, Sankar J, Andrea FM: Efficacy study of whitening toothpaste containing lemon (Citrus Limon (L) and salt (Sodium Carbonate). Dent Oral Health 2: 1-4, 2019. https://doi.org/10.33552/OJDOH.2019.02.000538

24. Lee KH, Kim S: Utilization of resin infiltration for prolonging of tooth whitening effects. J Korean Acad Pediatr Dent 44: 1-10, 2017.

https://doi.org/10.5933/JKAPD.2017.44.1.1

25. Jeong MJ, Kil KS, Lee MH, et al.: Inflammatory effect of light-emitting diodes curing light irradiation on Raw264.7 macrophage. J Dent Hyg Sci 19: 133-140, 2019.

https://doi.org/10.17135/jdhs.2019.19.2.133
26. Bogdan C: Nitric oxide and the immune response. Nat Immunol 2: 907-916, 2001. https://doi.org/10.1038/ni1001-907

27. Park M, Kim GH: The antioxidative and antibrowning effects of citrus peel extracts on fresh-cut apples. Korean J Food Sci Technol 45: 598-604, 2013.

https://doi.org/10.9721/KJFST.2013.45.5.598

28. Brunette DM: Effects of baking-soda-containing dentifrices on oral malodor. Compend Contin Educ Dent Suppl 18: S22-S32; quiz S46, 1997.

29. Kawakami T, Koike A, Amano F: Sodium bicarbonate regulates nitric oxide production in mouse macrophage cell lines stimulated with lipopolysaccharide and interferon $\gamma$. Nitric Oxide 79: 45-50, 2018. https://doi.org/10.1016/j.niox.2018.07.008

30. Ellis MF: Use of bicarbonate in patients with metabolic acidosis. Crit Care Nurse 35: 73-75, 2015.

https://doi.org/10.4037/ccn2015502 